\title{
First report of an accident with the speckled forest pit viper (Bothriopsis taeniata) in Brazil
}

\author{
Primeiro registro de acidente pela jararaca estrela \\ (Bothriopsis taeniata) no Brasil
}

\author{
Pasesa Q. Torrez ${ }^{1}$, Marcelo R. Duarte ${ }^{3}$, Francisco O.S. França ${ }^{1,2}$, Ligia Figueiredo ${ }^{1}$, \\ Paulo Abati ${ }^{1}$, Luciana R. Campos ${ }^{1}$, Pedro Pereira de Oliveira Pardal ${ }^{4}$, Mariana Quiroga ${ }^{1}$, \\ Melissa Mascheretti ${ }^{1}$ and Marcos Boulos ${ }^{1}$
}

\begin{abstract}
RESUMO
Relatamos o primeiro caso de acidente por Bothriopsis taeniata no Brasil. A vítima, trabalhador rural com 43 anos de idade, foi picada pouco acima do calcanhar direito, apresentando quadro clínico compatível por envenenamento botrópico leve: discreto edema com hemorragia no local da picada e dor, embora com ausência de coagulopatia.
\end{abstract}

Palavras-chaves: Bothriopsis taeniata. Acidente botrópico. Amazônia.

\begin{abstract}
The first reported case of an accident with Bothriopsis taeniata in Brazil is described. The victim, a 43-year-old man, was bitten just above his right heel and presented a clinical condition compatible with mild Bothrops poisoning: local edema with hemorrhage at the bite site and pain, although without coagulopathy.
\end{abstract}

Key-words: Bothriopsis taeniata. Bothrops accident. Amazon region.

Viperidae snake poisoning is considered a public health problem in many regions, especially in subtropical and tropical countries $^{41116}$, causing both morbidity and mortality. 25,364 snakebites were notified in Brazil in 2008, with a mortality rate of 100 deaths/year". Bothrops bites represent on average $90 \%$ of all poisonous snakebites in this country. There are six South American species in the genus Bothriopsis (family Viperidae), commonly known as forest pit vipers, and they range greatly in size ${ }^{2}$. Two species (Bothriopsis bilineata and Bothriopsis taeniata) are found in lowland rainforests and both of them are considered semi-arboreal species ${ }^{6}$. Bothriopsis taeniata is a rare pit viper in Brazil $^{16}$ and is almost never detected, because of the resemblance of its cryptic body to leaves and lichens on the forest floor. This paper reports on an authenticated case of a bite by this species and reviews the known literature on its venom.

\footnotetext{
1. Advanced Tropical Medicine Center, Santarém, PA/Department and Division of Infectious and Parasitic Diseases, School of Medicine, University of São Paulo, São Paulo, SP, Brazil. 2. Vital Brazil Hospital, Butantan Institute, São Paulo, SP, Brazil 3. Laboratory of Herpetology, Butantan Institute, São Paulo, SP, Brazil. 4. Tropical Medicine Center, School of Medicine, University of Pará, Belém, PA, Brazil. Address to: Dr. Francisco O.S. França. Hospital Vital Brazil/Instituto Butantan. Av. Vital Brazil, 1500, 05503-900 São Paulo, SP, Brazil

Tel: 5511 3726-7222 ramal 2000, Fax: 5511 3726-1505

e-mail: fosfranca@butantan.gov.br

Received in 23/12/2008

Accepted in 29/04/2009
}

\section{CASE REPORT}

In November 2007, a 43-year-old man was bitten just above his right ankle by a snake, while working on a rural site. He did not apply a tourniquet or attempt to cut or suck the wound. He immediately washed the wound with water and then alcohol, and took a homemade plant-based medicine labeled Pau-X (of unknown composition and formula ${ }^{3}$ ). He had previously been bitten by an unidentified Bothrops sp in 1998, according to the Santarem City Hospital records. He walked a short distance immediately after the snakebite to seek help, and was admitted to the emergency department of Santarém City Hospital (State of Pará, northern Brazil), 2⿺辶2 hours after the accident. The bite site presented minimal bleeding, but swelling had developed to just below the knee (Figure 1). He was conscious, in good general condition and vital signs were normal. Coagulation tests were normal, and a peripheral blood film revealed the following: platelets $162,000 / \mathrm{mm}^{3}$ (normal values: 150,000 400,000); hemoglobin 15.5g/dl (14-17.4g\%); hematocrit 43\% (41.5-50.4\%); white blood cells $11,500 / \mathrm{mm}^{3}(4,400-11,300 /$ $\mathrm{mm}^{3}$ ) with $83 \%$ segmented (1-5\%); 13\% lymphocytes (18-40\%); $2 \%$ eosinophils (1-4\%); urea 34mg/dl (10-50mg/dl); creatinine $1.20 \mathrm{mg} / \mathrm{dl}(0.4-1.3 \mathrm{mg} / \mathrm{dl})$, creatine kinase 267U/l (38-174U/); and lactate dehydrogenase 344U/1 (100-190U/1).

The patient brought the dead adult snake with him (total length of $120 \mathrm{~cm}$, Figure 2), and this was identified by comparison 


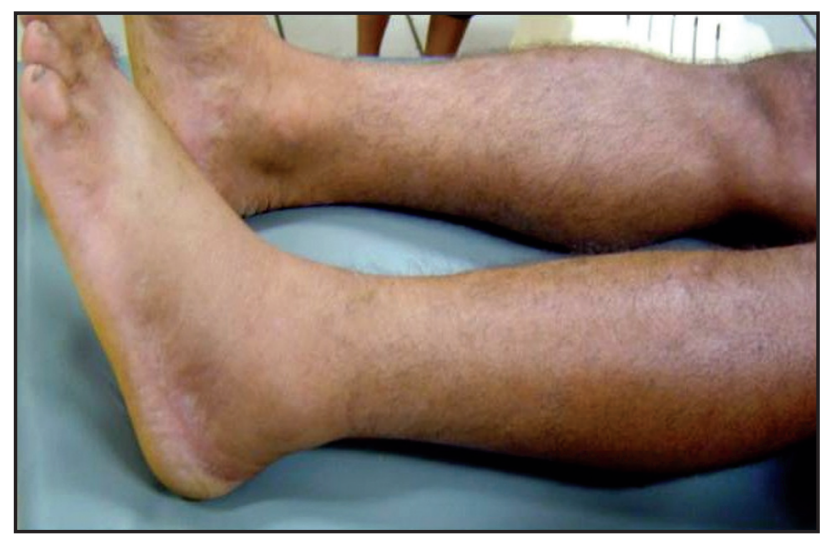

FIGURE 1

Ecchymosis and edema in the left ankle, two and a half hours after the bite.

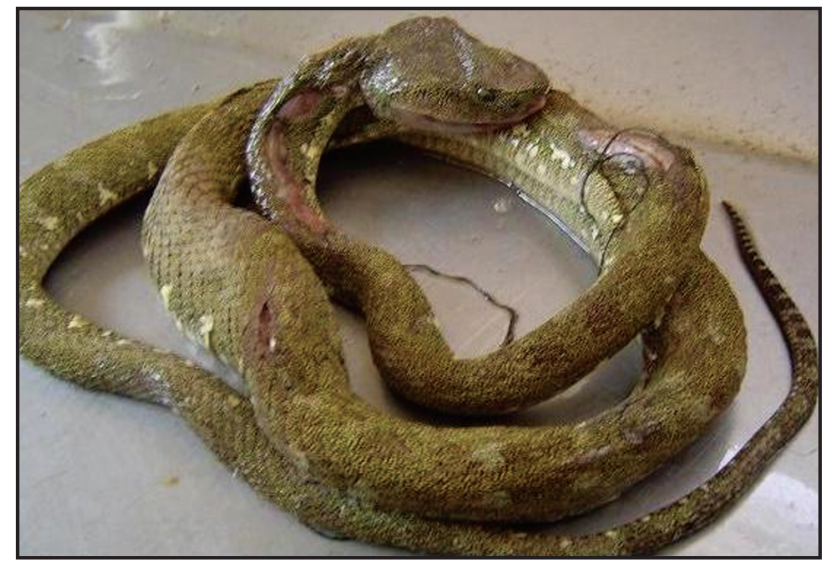

FIGURE 2

The speckled forest pit viper (Bothriopsis taeniata) that bit the patient.

with digital images as a specimen of Bothriopsis taeniata, by the Herpetology Laboratory of the Butantan Institute, São Paulo, southeastern Brazil. Unfortunately, the specimen was then discarded. He received four vials of anti-Bothrops antivenom after administration of dipyrone, cimetidine and hydrocortisone in accordance with the guidelines of the Brazilian Ministry of Health ${ }^{14}$. The leg swelling reduced and the patient was discharged in a good condition, without complications, on the second day after the accident.

\section{DISCUSSION}

The Amazon region represents almost $60 \%$ of Brazil, and snakebites are common in this region. It is rare for the animal involved in the accident to be brought in by the victim ${ }^{8}$. Seven Viperidae occurs in the Brazilian Amazon region (Bothrops atrox, Bothrops brazili, Bothriopsis bilineatus, Bothriopsis taeniata, Bothrocophias byoprora, Crotalus durissus and Lachesis muta $)^{16}$. The genus Bothriopsis is represented by six species in South America. Bothriopsis taeniata can be found from sea level up to at least $2,133 \mathrm{~m}^{2}$. Bothriopsis taeniata has exceptionally long fangs ${ }^{2}$, and the largest size attained by this species is $180 \mathrm{~cm}$ in total length ${ }^{17}$. The efficacy of three
Latin American antivenoms administered to 210 patients bitten by snakes was compared in Ecuador ${ }^{17}$. In that study, twenty nine (14\%) of the victims brought in the snake responsible for the bite. Six of the accidents were caused by Bothriopsis taeniata, but only two of these victims brought in the snakes (which were 150 and $180 \mathrm{~cm}$ in total length), while the remainder were identified by enzyme immunoassay. Two cases of bites in Ecuador and Peru by Bothriopsis taeniata, both of them on the lower leg, have been reported ${ }^{18}$. Bothriopsis taeniata has been described as a semi-arboreal but predominantly terrestrial pit viper ${ }^{6}$, but also as canopy dweller ${ }^{2}$. Paradoxically, the prevalence of bites on lower limbs suggests that this snake has significant terrestrial activity. Unfortunately, data on the patients in such cases, as well as on the snake, are very limited.

To the best of our knowledge, this is the first authenticated case report of a bite by this species in Brazil. The venom from Bothrops species has coagulant, hemorrhagic and local inflammatory activity $^{710}$. Bothriopsis bilineata and Bothriopsis taeniata have high proteolytic activity on thrombin, plasmin, kallikrein, and cathepsin $\mathrm{C}^{15}$. Bothriopsis taeniata from Ecuador presented hemorrhagic, anticoagulant and myotoxic activity ${ }^{15}$. Bothriopsis taeniata (formerly Bothrops castelnaudi) has anticoagulant activity that has been attributed to in vitro inhibition of factor $\mathrm{X}$ and prothrombin ${ }^{12}$. Although anti-Bothrops serum has been formulated from a pool of five coagulant Bothrops venoms (Bothrops alternatus, Bothrops jararaca, Bothrops jararacussu, Bothrops moojeni and Bothrops neuwiedi) ${ }^{12}$, it neutralized the anticoagulant effect of Bothriopsis taeniata. Bothriopsis taeniata venoms induced neutrophil migration and induced significant hemorrhaging in the peritoneal cavity of mice, thus suggesting that this venom has hemorrhagic activity caused by metalloproteinases ${ }^{15}$.

In conclusion, this case report has shown that the venom of Bothriopsis taeniata caused a clinical condition compatible with mild Bothrops poisoning without coagulopathy. Furthermore, because of this snake's camouflaging (i.e. the resemblance of the snake's body to leaves and lichens on the forest floor), some of the other accidents with local swelling and hemorrhage that have occurred in the Amazon region may have been caused by Bothriopsis species.

\section{ACKNOWLEDGEMENTS}

We thank the staff of Hospital Municipal de Santarém, Pará, for their assistance.

\section{REFERENCES}

1. Brazil V. A defeza contra o ophidismo. Pocai \& Weiss, São Paulo, 1911.

2. Campbell JA, Lamar WW. The venomous reptiles of the Latin America. Comstock Publishing Associates, Ithaca, 2004.

3. Cardoso JLC. A fitoterapia antiveneno na Medicina brasileira. In: Cardoso JLC, França FOS, Hui FW, Malaque CMS, Haddad Jr V (eds) Animais Peçonhentos no Brasil. Editora Sarvier, São Paulo, p. 429-433, 2003. 
4. Chippaux JP. Snake-bites: Appraisal of the global situation. Bulletin of the World Health Organization 75: 515-524, 1998.

5. Cunha OR, Nascimento FP. Ofídios da Amazônia - Sobre a ocorrência de Bothrops lichenosus Roze, 1958 no Brasil (Ophidia, Crotalidae). Revista Brasileira de Biologia 32: 27-32, 1972.

6. Cunha OR, Nascimento FP. Ofídios da Amazônia. X - As cobras da região leste do Pará. Belém: Museu Paraense Emílio Goeldi, 1978.

7. Farsky SH, Antunes E, Mello SBV. Pro and Antiinflamatory properties of Toxins from Animal Venoms Alergy. Inflammation and Allergy 4: 401-411, 2005.

8. França FOS, Malaque CMS. Acidente botrópico. In: Cardoso JLC, França FOS, Hui FW, Malaque CMS, Haddad Jr V (eds) Animais Peçonhentos no Brasil. Editora Sarvier, São Paulo, p. 72-86, 2003.

9. Fundação Nacional de Saúde/Animais Peçonhentos/SVS/Ministério da Saúde, Brasília, 2002. Acessado em 7 de janeiro de 2009. http://dtr2004.Saude.gov.br/ Sinanweb/tabnet/dh?sinan/animaisp/bases/animaisbr.def

10. Guércio RAP, Shevchenko A, López-Lozano JL, Sousa MV, Ricart CAO. Ontogenetic variations in the venom proteome of the Amazonian snake Bothrops atrox. Proteome Science 4: 1186-1477, 2006

11. Gutiérrez JM, Theakston RD, Warrell DA. Confronting the Neglected Problem of SnakeBite Envenoming: The Need for a Global Partnership. PLoS Medicine 3: 6-150, 2006
12. Kamiguti AS, Sousa e Silva MCC, Morena P, Nahas L. The anticoagulant effect of Bothrops castelnaudi snake venom (Castelnaud's Pit Viper). Toxicon 23: 383-391, 1985.

13. Kuch U, Mebs D, Gutiérrez JM, Freire, A. Biochemical and biological characterization of ecuatorian pitviper venoms (Genera Bothriechis, Bothriopsis, Bothrops and Lachesis). Toxicon 34: 714-717, 1996

14. Ministério da Saúde. Manual de Diagnóstico e Tratamento de Acidentes por Animais Peçonhentos. Brasília, 1998

15. Porto BN, Tellib CA, Dutra,TP, Alves LS, Bozza MT, Fin CA, Thiesen FV, Renner MF Biochemical and biological characterization of the venoms of Bothriopsis bilineata and Bothriopsis taeniata (Serpentes: Viperidae). Toxicon 50: 270-277, 2007.

16. Santos MC. Serpentes peçonhentas e ofidismo no Amazonas. In: Cardoso JLC, França FOS, Hui FW, Malaque CMS, Haddad Jr V (eds) Animais Peçonhentos no Brasil. Editora Sarvier, São Paulo, p.115-125, 2003.

17. Smalligan R, Cole J, Brito N, Laing GD, Mertz BL, Manock S, Maudlin J, Quist B, Holland G, Nelson S, Lalloo DG, Rivadeneira G, Barragan ME, Dolley D, Eddleston M, Warrell DA, Theakston DG. Crotaline snake bite in the Ecuadorian Amazon randomised double blind comparative trial of three South American polyspecific antivenoms. British Medical Journal 329: 1129, 2004

18. Warrell DA. Snakebites in Central and South America: epidemiology, clinical features, and clinical management. In: Cardoso JLC, França FOS, Hui FW, Malaque CMS, Haddad Jr V (eds) Animais Peçonhentos no Brasil. Editora Sarvier, São Paulo, p.709-761, 2004 